\title{
Evaluation of Glycemic, Lipid, Immune-Inflammatory and Oxidative Stress Markers in Various Clinical Stages of Type 2 Diabetic Nephropathy
}

Srilatha Reddy Gantala ${ }^{1}$, Ramanjaneyulu Kummari ${ }^{1}$, Mohini Ayiengar Tupurani ${ }^{1}$, Rajesh Kumar Galimudi ${ }^{1}$, Kishore Kumar Gundapaneni ${ }^{1}$, Keerthi Kupsal ${ }^{1}$, Nivas Shyamala ${ }^{1}$, Surekha Rani Hanumanth ${ }^{1^{*}}$ and Swarnalatha Guditi ${ }^{2}$

${ }^{1}$ Department of Genetics, Osmania University, Hyderabad, Telangana State, India

${ }^{2}$ Nizam's Institute of Medical Sciences (NIMS), Hyderabad, Telangana State, India

*Corresponding author: Dr Surekha Rani H, Assistant Professor, Department of Genetics, Osmania University, Hyderabad-500007, India, Tel: +91-40-2768-2335; Email: surekharanih@gmail.com

Received date: February 16, 2018; Accepted date: February 27, 2018; Published date: March 06, 2018

Copyright: $\odot 2018$ Gantala SR, et al. This is an open-access article distributed under the terms of the creative commons attribution license, which permits unrestricted use, distribution, and reproduction in any medium, provided the original author and source are credited.

\begin{abstract}
Type 2 Diabetic nephropathy (DN), chronic multifactorial disorder is a devastating complication of DM and a main cause of end stage renal failure. A variety of factors like metabolic, hemodynamic, genetic and multiple pathogenic events contribute to the renal damage in type $2 \mathrm{DN}$. The present study was designed to assess blood glucose, serum lipid profiles, immune-inflammatory and oxidative stress markers in type 2 DN patients in different stages of the disease and healthy controls. Our study showed that FBS, PPG, HbA1c, TC, TG, LDL-C, ADA, CRP, MDA, NO and DNA damage were significantly high in type $2 \mathrm{DN}$ patients $(p<0.01)$ compared to controls. In stage wise comparison also FBS, PPG, HbA1c, LDL-C, CRP, MDA, NO and DNA damage showed significant difference $(p<0.05)$. Further, a significant positive correlation was found between PLBS, LDL-C and CRP and oxidative stress markers (MDA, NO, DNA damage) suggesting that monitoring these biochemical parameters at regular intervals may reduce the stage wise progression of type $2 \mathrm{DN}$ and might help in early detection, precise prognosis/therapeutic modalities.
\end{abstract}

Keywords: Type 2 diabetic nephropathy; HbA1c; Lipid profiles; Immune-Inflammatory; Oxidative stress markers; DNA damage

\section{Introduction}

Globally the incidence of diabetes mellitus (DM) is increasing in all age-groups and the prevalence was estimated to be $2.8 \%$ (175 million people) in 2000 while recent trends show that it might increase to $4.4 \%$ (366 million people) in 2030 [1]. Type 2 diabetic nephropathy (DN) can conveniently be categorized into different stages with respect to renal hemodynamic, systemic blood pressure, urinary findings and susceptibility to therapeutic interventions. The glycosylated hemoglobin (HbAlc) levels in most type $2 \mathrm{DN}$ patients were indicative of uncontrolled DM [2].

Prolonged hyperglycemia induces dyslipidemia in type 2 DN. Lipids may induce both glomerular and tubulointerstitial injury through inflammatory mediators, ROS and through hemodynamic changes $[3,4]$. Immune-inflammatory disturbances in type 2 diabetics have an association with cell mediated responses, inappropriate T-lymphocyte function and low-grade inflammatory status, which further leads to the increased production of oxidative stress associated with type $2 \mathrm{DN}$. This inflammation and oxidative stress are both deeply inter-related and are known to play an important role in diabetic vascular complications [5].

Type 2 diabetes in India harbors the largest number of diabetics, among which incidence of $\mathrm{DN}$ is on rise. In view of the above, the present study has been explored to study the association of blood glucose levels, HbA1c, lipid profiles, immune-inflammatory markers (ADA \& CRP), oxidative stress markers (MDA, NO \& COMET) and their susceptibility to type $2 \mathrm{DN}$ patients and its progression to endstage renal disease (ESRD).

\section{Materials and Methods}

\section{Study subjects}

The present study population consisted of a total of 620 subjects including 310 patients recruited from Department of Nephrology, Nizam Institute of Medical Sciences, Hyderabad, Telangana state, INDIA, with type $2 \mathrm{DN}$ and an equal number of healthy individuals without any systemic disorders from the local population included in the study (medical history \& physical examination). Patients undergoing anti-diabetic treatment were enrolled from the department of nephrology between the period from March 2012 to August 2017.

Inclusion criteria: All the type $2 \mathrm{DN}$ patients enrolled for the study had a minimum of 5 years history of type 2 diabetes mellitus with fasting sugar $>110 \mathrm{mg} / \mathrm{dl}$ and postprandial blood sugar $>140 \mathrm{mg} / \mathrm{dl}$ respectively and serum creatinine $<1.2 \mathrm{mg} / \mathrm{dl}$ as defined by clinical presentation by nephrologist will be included in the study.

Exclusion criteria: Patients presenting with systemic inflammatory disease, liver disease, congestive heart failure, malignancy, and AIDS were excluded from the study. Patients on treatment with ACE inhibitors, lipid lowering agents, anti-inflammatory drugs, anti-oxidant and multivitamin supplements were excluded from the study.

According to the pathological classification of Tervaert et al. (2010) based on glomerular lesions and GFR rate the 310 type $2 \mathrm{DN}$ patients were categorized into stages: stage-1: 33 (10.64\%), stage-2: $49(15.8 \%)$, stage-3: 112 (36.1\%), stage-4: 78 (25.16\%), and stage-5: 38 (12.25\%). The study protocol was approved by the ethical committee of the institution, written informed consent was obtained from all the subjects. 
Citation: Gantala SR, Kummari R, Tupurani MA, Galimudi RK, Gundapaneni KK, et al. (2018) Evaluation of Glycemic, Lipid, ImmuneInflammatory and Oxidative Stress Markers in Various Clinical Stages of Type 2 Diabetic Nephropathy. J Metabolic Synd 7: 237. doi: 10.4172/2167-0943.1000237

Page 2 of 7

\section{Covariables}

In the present study covariables include gender, age, body mass index (BMI), diabetes, hypertension, serum creatinine, glomerular filtration rate (GFR), hyperlipidemia, urea, diet, smoking and alcohol. The BMI of the subjects was computed by dividing the body weight by square of the height. The blood pressures of subjects were measured with sphygmo-manometer by clinician, hypertension was defined as systolic blood pressure $>130 \mathrm{~mm} / \mathrm{Hg}$ and/or diastolic pressure $>80$ $\mathrm{mm} / \mathrm{Hg}$.

Alkaline Picrate method used for estimation of creatinine in serum. GFR values were calculated by Cockcroft-Gault equation. $\mathrm{Ccr}=\{((140-$ age) $\times$ Weight $) / 72 \times \mathrm{Scr}\} \times 0.85$ (if female). Diacetyl Monoxime (DAM) method is used for determination of urea in serum. Smoking and alcoholism were defined as positive for current smokers and alcoholics.

\section{Blood sample collection}

From each subject $8 \mathrm{ml}$ of blood sample was drawn in the morning after a $12 \mathrm{~h}$ fast (from $8 \mathrm{pm}$ to $8 \mathrm{am}$ ) and in the afternoon $1 \mathrm{~h}$ after lunch; where, $4 \mathrm{ml}$ of the blood sample was collected in EDTA tubes for the determination of glycated hemoglobin and comet assay. $4 \mathrm{ml}$ of blood sample was collected in a clot activator tube and left to clot to obtain serum, which was used for the other biochemical estimations like glucose, lipids, immune-inflammatory and oxidative stress markers.

\section{Estimation of biochemical markers}

Fasting blood sugar (FBS) and postprandial blood sugar (PLBS) were analyzed by ERBA kit (Transasia, Germany), glycosylated hemoglobin $(\mathrm{HbAlc})$ was measured by Fluckiger and Winterhalter calorimetric method [6].

Lipid profile (Total cholesterol (TC), Triglyceride (TG), High density lipoprotein cholesterol (HDL-C) were carried out by commercially available kits (ERBA, Transasia, Germany). LDL-C was calculated using the Friedewald's formula: LDL-C = total cholesterol (HDL - triglycerides/5) mg/dL [7].

Serum adenosine deaminase (ADA) levels were estimated by the method of Giusti and Galanti (1981) [8] and serum circulating levels of C-reactive protein (CRP) were determined by Immunoturbidimetric method using RHELAX-CRP kit (Latex Agglutination slide test for detection of CRP) [TULIP diagnostics (P) LTD., INDIA].

Oxidative stress markers, MDA was measured by thiobarbituric acid (TBA) using Meloni et al., (1992) [9] method. Nitric oxide was estimated using Griess reagent (1:1 mixture of 1\% sulphanilamide in 5\% H3PO4 and 0.1\% N-[1-naphthyl] ethylene diamine) using Lepoivre et al., (1990) [10] method, DNA damage was assessed by Comet assay using Singh et al., [11] and Ahuja (1999) [12] methods.

\section{Statistical analysis}

All statistical analyses were performed with online statistical software tools such as Open Epi version 3.03. Differences in demographic, clinical, and biochemical variables were statistically analyzed by one-way ANOVA in type $2 \mathrm{DN}$ patients and healthy controls. All p-values $\leq 0.05$ were considered statistically significant. All numeric values are expressed as the mean \pm SD. Pearson's correlation coefficient (r) was used to quantify continuous variables such as hyperglycemia (fasting and postprandial), HbAlc, lipid profiles, ADA, CRP with oxidative stress markers using SPSS statistical software (version 20).

\section{Results}

The distribution of baseline demographic and biochemical data in healthy individuals (310) and type $2 \mathrm{DN}$ patients (310) are represented in (Table 1 and Figure 1) and among type 2 DN stages are depicted in (Table 2 and Figure 2). With respect to age no significant difference observed between controls and type $2 \mathrm{DN}$ patients (Table 1 ) however the mean age of patients in stage 4 and 5 was high when compared to patients in stages 1,2 and 3 but no significant difference observed among the type $2 \mathrm{DN}$ clinical stages (Table 2). The number of males was more than that of females in the patient population. Mixed diet, habit of smoking and alcohol consumption were also higher in-patient population (Figure 1).

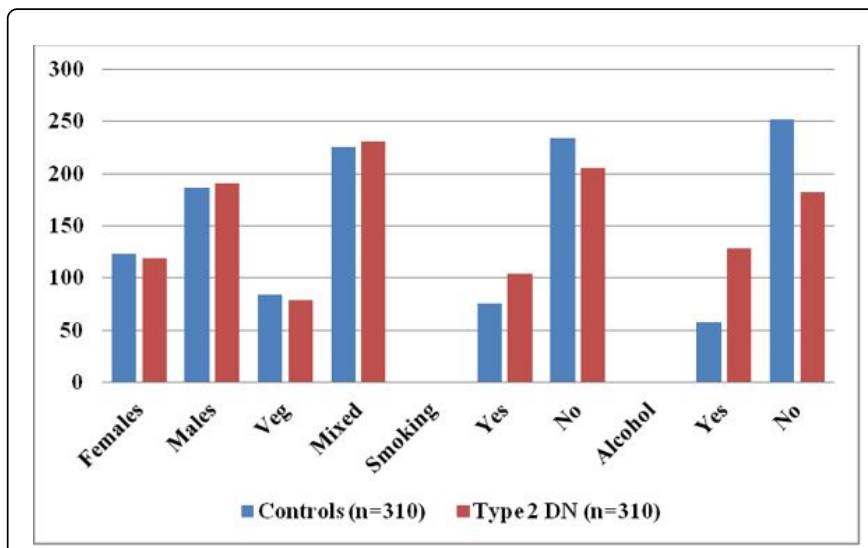

Figure 1: Demographic data in controls and type $2 \mathrm{DN}$ patients.

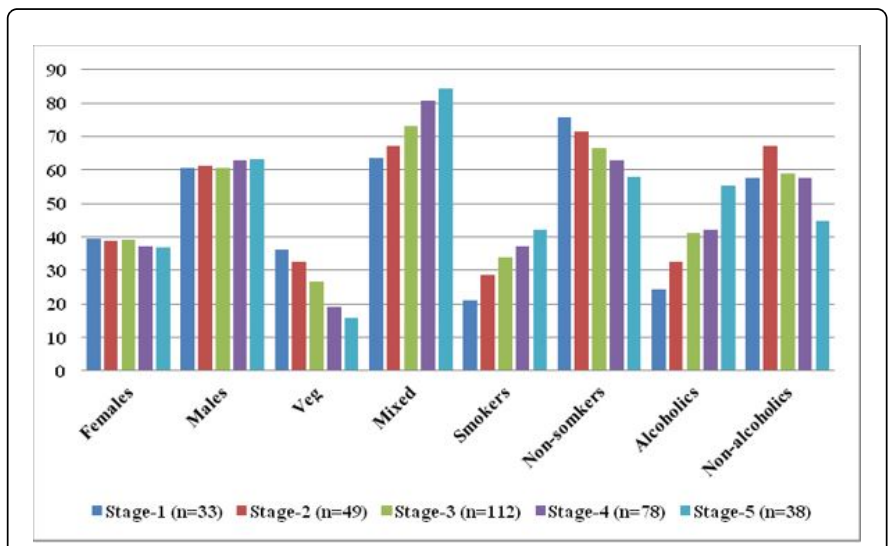

Figure 2: Demographic data of patients among type 2 DN stages.

\begin{tabular}{|l|l|l|l|}
\hline & $\begin{array}{l}\text { Controls } \\
\mathbf{( N = 3 1 0 )}\end{array}$ & $\begin{array}{l}\text { Type 2 DN } \\
(\mathbf{N = 3 1 0 )}\end{array}$ & p-value \\
\hline Age (years) & $52.84 \pm 7.99$ & $56.92 \pm 8.77$ & 0.1 \\
\hline Systolic BP $(\mathrm{mmHg})$ & $121.23 \pm 7.37$ & $136.5 \pm 13.99$ & $0.01^{*}$ \\
\hline Diastolic BP $(\mathrm{mmHg})$ & $80.88 \pm 7.02$ & $86.32 \pm 14.66$ & $0.01^{*}$ \\
\hline
\end{tabular}


Citation: Gantala SR, Kummari R, Tupurani MA, Galimudi RK, Gundapaneni KK, et al. (2018) Evaluation of Glycemic, Lipid, ImmuneInflammatory and Oxidative Stress Markers in Various Clinical Stages of Type 2 Diabetic Nephropathy. J Metabolic Synd 7: 237. doi: $10.4172 / 2167-0943.1000237$

Page 3 of 7

\begin{tabular}{|l|l|l|l|}
\hline HBA1c & $5.12 \pm 2.65$ & $10.66 \pm 5.78$ & $0.01^{*}$ \\
\hline $\begin{array}{l}\text { Serum } \\
\text { (mg/dL) }\end{array}$ & $0.91 \pm 0.24$ & $2.04 \pm 0.38$ & $0.01^{*}$ \\
\hline Urea (mmol/24h) & $18.16 \pm 4.63$ & $96.17 \pm 7.17$ & $0.01^{*}$ \\
\hline *Significant at $\mathrm{p}<0.01$ & & \\
\hline
\end{tabular}

Table 1: Baseline and biochemical parameters in controls and type 2 DN patients.

\begin{tabular}{|c|c|c|c|c|c|c|}
\hline Parameter & $\begin{array}{l}\text { Stage- } 1 \\
(\mathrm{~N}=33)\end{array}$ & $\begin{array}{l}\text { Stage- } 2 \\
(\mathrm{~N}=49)\end{array}$ & $\begin{array}{l}\text { Stage- } 3 \\
(\mathrm{~N}=112)\end{array}$ & $\begin{array}{l}\text { Stage- } 4 \\
(N=78)\end{array}$ & $\begin{array}{l}\text { Stage- } 5 \\
(\mathrm{~N}=38)\end{array}$ & $p$-value \\
\hline Age (years) & $\begin{array}{l}54.30 \quad \pm \\
8.99\end{array}$ & $\begin{array}{l}54.69 \pm \\
8.84\end{array}$ & $\begin{array}{l}56.59 \quad \pm \\
8.84\end{array}$ & $\begin{array}{l}59.11 \pm \\
7\end{array}$ & $\begin{array}{l}59.92 \\
10.20\end{array}$ & 0.72 \\
\hline BMI $\left(\mathrm{kg} / \mathrm{m}^{2}\right)$ & $\begin{array}{l}25.44 \quad \pm \\
3.16\end{array}$ & $\begin{array}{l}25.80 \pm \\
4.21\end{array}$ & $\begin{array}{l}25.82 \quad \pm \\
4.72\end{array}$ & $\begin{array}{l}26.48 \quad \pm \\
3.81\end{array}$ & $\begin{array}{l}25.33 \quad \pm \\
4.10\end{array}$ & 0.61 \\
\hline $\begin{array}{l}\text { Systolic BP } \\
(\mathrm{mmHg})\end{array}$ & $\begin{array}{l}134.24 \pm \\
10.79\end{array}$ & $\begin{array}{l}135.12 \pm \\
12.19\end{array}$ & $\begin{array}{l}135.20 \pm \\
14.83\end{array}$ & $\begin{array}{l}138.28 \pm \\
15.88\end{array}$ & $\begin{array}{l}139.69 \pm \\
16.29\end{array}$ & $0.04^{*}$ \\
\hline $\begin{array}{l}\text { Diastolic BP } \\
(\mathrm{mmHg})\end{array}$ & $\begin{array}{ll}83.48 & \pm \\
12.77 & \end{array}$ & $\begin{array}{l}84.12 \\
14.18\end{array}$ & $\begin{array}{l}86.55 \quad \pm \\
14.96\end{array}$ & $\begin{array}{l}87.92 \\
15.12\end{array}$ & $\begin{array}{l}89.53 \quad \pm \\
16.30\end{array}$ & $0.02^{*}$ \\
\hline HbA1c (\%) & $\begin{array}{ll}9.83 & \pm \\
4.24 & \end{array}$ & $\begin{array}{ll}9.93 & \pm \\
5.28 & \end{array}$ & $\begin{array}{l}10.62 \quad \pm \\
5.92\end{array}$ & $\begin{array}{l}10.80 \quad \pm \\
6.53\end{array}$ & $\begin{array}{l}12.14 \quad \pm \\
6.94\end{array}$ & $0.03^{*}$ \\
\hline $\begin{array}{l}\text { Serum } \\
\text { Creatinine } \\
\text { (mg/dL) }\end{array}$ & $\begin{array}{l}1.26 \\
0.21\end{array}$ & $\begin{array}{ll}1.37 & \pm \\
0.26 & \end{array}$ & $\begin{array}{ll}1.9 & \pm \\
0.34 & \end{array}$ & $\begin{array}{ll}2.5 & \pm \\
0.48 & \end{array}$ & $\begin{array}{ll}3.22 & \pm \\
0.62 & \end{array}$ & $0.01^{*}$ \\
\hline $\begin{array}{l}\text { Urea }(\mathrm{mmol} / \\
24 \mathrm{~h})\end{array}$ & $\begin{array}{l}80.95 \\
4.91\end{array}$ & $\begin{array}{l}90.23 \quad \pm \\
5.82\end{array}$ & $\begin{array}{ll}98.64 & \pm \\
7.82 & \end{array}$ & $\begin{array}{l}100.41 \pm \\
8.55\end{array}$ & $\begin{array}{l}110.62 \pm \\
8.75\end{array}$ & $0.01^{*}$ \\
\hline
\end{tabular}

Table 2: Baseline and biochemical parameters in different stages of type $2 \mathrm{DN}$.

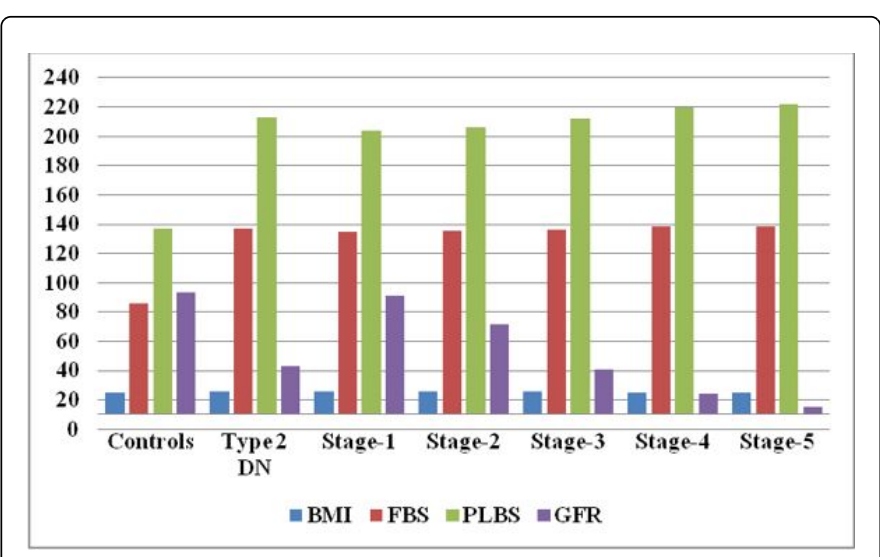

Figure 3: Clinical parameters in the study population.

The distribution of clinical parameters BMI, FBS, PLBS and GFR in the study population are represented in Figure 3. There was no significant difference with respect to BMI among the study subjects. Glycemic parameters FBS and PLBS levels were higher in patient and showed a gradual increase in different stages of type $2 \mathrm{DN}$ compared to controls $(p<0.01)$. Serum creatinine and GFR are commonly used parameters to indicate renal dysfunction [13]. The GFR values showed

decreasing trend among type $2 \mathrm{DN}$ stages suggesting the reduced kidney function from stage-1 to stage-5 (Figure 3).

Lipid profiles of the study subjects are represented in Figure 4. Our results revealed that TC, TG, LDL levels were significantly higher in type 2 DN stages compared to controls $(\mathrm{p}<0.01)$, whereas LDL levels were significantly increased in type $2 \mathrm{DN}$ stages from stage- 1 to stage 5 compared to controls $(\mathrm{p}<0.01)$. The mean SBP and DBP values were significantly high in type $2 \mathrm{DN}$ compared to controls $(\mathrm{p}<0.01)$ (Table 1 ) and there was a progressive increase in SBP and DBP values from stage 1 to stage 5 which was also found to be significant at $(\mathrm{p}<0.04)$ and $(\mathrm{p}<0.02)$. Mean HbA1c levels of type $2 \mathrm{DN}$ found to be more than that of controls which was found significant at $(\mathrm{p}<0.01)$ (Table 1$)$. The mean $\mathrm{HbA1c}$ levels of patients also increased from stage 1 to stage 5 of type $2 \mathrm{DN}$ patients $(\mathrm{p}<0.01)$ (Table 2). Mean serum creatinine and urea levels were found be more compared to controls which was significant at $(\mathrm{p}<0.01)$ (Table 1). Serum creatinine and urea levels showed gradual increase from stage- 1 to stage -5 with the advanced stage of the disease which was found to be significant at (One-way ANOVA, $\mathrm{p}<0.01$ ) (Table 2).

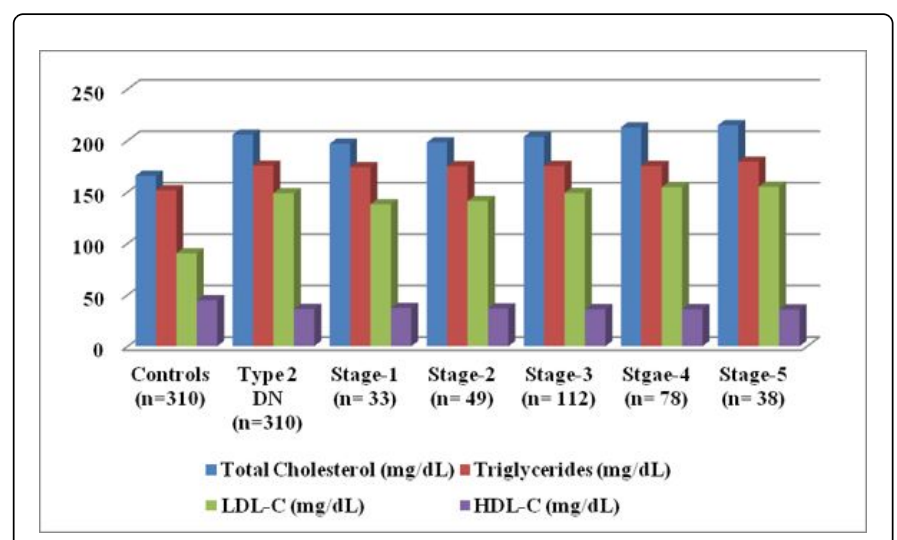

Figure 4: Lipid profiles in the study population.

The prevalence of nephropathy is strongly related to the duration of diabetes. In most individuals were with 5-10 years history of diabetes, i.e., stage 1: $69.69 \%$, stage 2: $65.30 \%$, and stage 3: $63.39 \%$ when compared to stage $4: 52.56 \%$ and stage $5: 26.31 \%$. Furthermore, $38.46 \%$ of the individuals in stage 4 were presented with 10-15 yrs of type 2 DM. While $44.73 \%$ individuals in stage 5 were reported with $10-15$ years and $28.94 \%$ were reported with $15-20$ yrs of duration of diabetes. Overall our results indicate that longer the duration of diabetes, higher is the risk for disease progression as shown in Table 3.

\begin{tabular}{|c|c|c|c|c|c|}
\hline $\begin{array}{l}\text { Duration } \\
\text { (years) }\end{array}$ & $\begin{array}{l}\text { Stage-1 } \\
(\mathrm{N}=33) \\
(\%)\end{array}$ & $\begin{array}{l}\text { Stage-2 } \\
(\mathrm{N}=49) \quad \mathrm{N} \\
(\%)\end{array}$ & $\begin{array}{l}\text { Stage-3 } \\
(\mathrm{N}=112) \quad \mathrm{N} \\
(\%)\end{array}$ & $\begin{array}{l}\text { Stage-4 } \\
(\mathrm{N}=78) \quad \mathrm{N} \\
(\%)\end{array}$ & $\begin{array}{l}\text { Stage-5 } \\
(\mathrm{N}=38) \quad \mathrm{N} \\
(\%)\end{array}$ \\
\hline $5-10$ & 23 (69.69) & $32(65.30)$ & 71 (63.39) & $41(52.56)$ & $10(26.31)$ \\
\hline $10-15$ & $9(27.27)$ & $15(30.61)$ & $35(31.25)$ & $30(38.46)$ & $17(44.73)$ \\
\hline $15-20$ & $1(3.0)$ & $2(4.08)$ & $6(5.35)$ & 7 (8.97) & $11(28.94)$ \\
\hline
\end{tabular}

Table 3: Duration of type 2 diabetes mellitus in different stages of type $2 \mathrm{DN}$.

Immune-inflammatory markers ADA and CRP levels were found to be higher in type $2 \mathrm{DN}$ patients compared to controls. The difference 
Citation: Gantala SR, Kummari R, Tupurani MA, Galimudi RK, Gundapaneni KK, et al. (2018) Evaluation of Glycemic, Lipid, ImmuneInflammatory and Oxidative Stress Markers in Various Clinical Stages of Type 2 Diabetic Nephropathy. J Metabolic Synd 7: 237. doi: $10.4172 / 2167-0943.1000237$

Page 4 of 7

in the mean values was statistically significant at $p<0.01$ (Table 4 ). The mean CRP of patients with different stages of type $2 \mathrm{DN}$ patients also showed significant difference, whereas no significant difference was observed with ADA in stage wise comparison (Table 5).

In the present study oxidative stress was measured by indices of lipid peroxidation (LP) (MDA: malondialdehyde) and nitric oxide (Nitrate/Nitrite). The mean level of malondialdehyde and DNA damage (Comet tail length) were significantly higher in type $2 \mathrm{DN}$ patients compared to controls as shown in Table 4 and Figure 5. In the present study the mean levels of MDA and DNA damage in patients with different stages of type $2 \mathrm{DN}$ patients also showed a gradual increase of these oxidative stress markers from stage 1 to stage 5 (Oneway ANOVA, p <0.01) (Table 5). The mean NO levels in type $2 \mathrm{DN}$ patients were high compared to controls which was significant at $\mathrm{p}<0.01$ shown in Table 4 , whereas no significant result was observed among type $2 \mathrm{DN}$ patients among different clinical stages (Table 5).

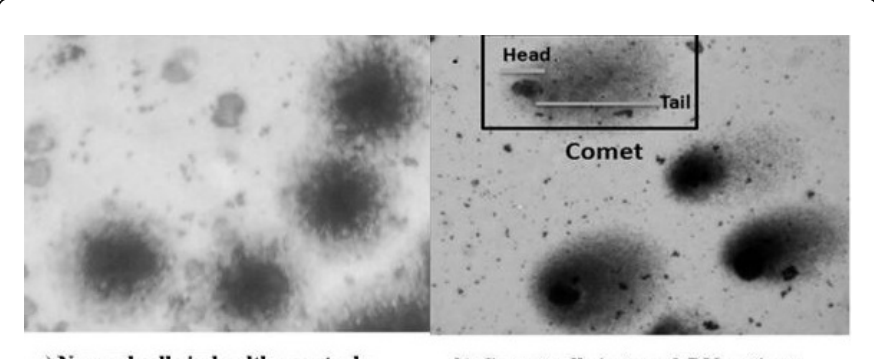

a) Normal cells in healthy controls

b) Comet cells in type 2 DN patients

Figure 5: Representative microscopic appearances of comet assay.

\begin{tabular}{|c|c|c|c|c|}
\hline Parameter & $\begin{array}{l}\text { Biochemical } \\
\text { variables }\end{array}$ & $\begin{array}{l}\text { Controls } \\
(\mathrm{N}=310)\end{array}$ & $\begin{array}{l}\text { Type 2 DN } \\
(\mathrm{N}=310)\end{array}$ & $p$-value \\
\hline & $\mathrm{CRP}(\mathrm{mg} / \mathrm{dL})$ & $10.00 \pm 6.70$ & $\begin{array}{ll}47.51 & \pm \\
14.69 & \end{array}$ & $0.01 \dagger$ \\
\hline \multirow{2}{*}{$\begin{array}{l}\text { Immune- } \\
\text { inflammatory } \\
\text { markers }\end{array}$} & $\begin{array}{l}\text { ADA } \\
\text { (nmoles } / \mathrm{mL} \text { ) }\end{array}$ & $15.69 \pm 5.55$ & $36.02 \pm 11.17$ & $0.01 \dagger$ \\
\hline & $\begin{array}{l}\text { NO } \\
(\mu \text { moles } / \mathrm{mL})\end{array}$ & $1.89 \pm 0.79$ & $3.51 \pm 1.35$ & $0.01 \dagger$ \\
\hline \multirow[b]{2}{*}{$\begin{array}{l}\text { Oxidative } \\
\text { stress markers }\end{array}$} & $\begin{array}{l}\text { MDA } \\
\text { (nmoles/mL) }\end{array}$ & $2.08 \pm 1.37$ & $7.86 \pm 2.69$ & $0.01 \dagger$ \\
\hline & $\begin{array}{l}\text { DNA Damage } \\
(\mu \mathrm{m})\end{array}$ & $10.55 \pm 1.68$ & $23.48 \pm 6.40$ & $0.01 \dagger$ \\
\hline
\end{tabular}

†Significant at $p<0.01$

All the variables are expressed as mean $\pm S D$

Table 4: Immune-inflammatory and oxidative stress markers in controls and type $2 \mathrm{DN}$ patients.

Hyperglycemic markers (FBS, PLBS and HbA1c) were correlated with oxidative stress markers and found that FBS was significantly associated with MDA and NO $(r=0.004, r=0.023, p<0.05)$, PLBS was found to be significantly associated with MDA, NO and DNA damage $(\mathrm{r}=0.052, \mathrm{r}=0.046, \mathrm{r}=0.016, \mathrm{p}<0.05)$ and HbAlc was found to be significantly associated with MDA and DNA damage $(r=0.035$, $\mathrm{r}=0.037, \mathrm{p}<0.05)$ (Table 6).
Lipid profiles when correlated with oxidative stress markers have revealed that TC was significantly associated with MDA and DNA damage ( $r=0.009, r=0.042, p<0.05)$, TG was found to be significantly associated with DNA damage $((\mathrm{r}=0.035, \mathrm{p}<0.05)$ and LDL-C was found to be significantly associated with MDA, NO and DNA damage $(\mathrm{r}=0.014, \mathrm{r}=0.004, \mathrm{r}=0.023, \mathrm{p}<0.05)$, while HDL-C was found to be negatively associated with MDA $(r=-0.027, \mathrm{p}<0.05)$ (Table 6).

Immune-inflammatory markers CRP, was found to be significantly associated with MDA, NO and DNA damage ( $r=0.026, r=0.041$, $\mathrm{r}=0.035, \mathrm{p}<0.05$ ) (Table 6), whereas ADA has shown no significant association with oxidative stress markers.

Blood glucose, lipid profile and inflammatory markers were correlated with oxidative stress markers and our results have shown that PLBS $(\mathrm{r}=0.052, \mathrm{r}=0.046, \mathrm{r}=0.016, \mathrm{p}<0.05)$, LDL-C $(\mathrm{r}=0.014$, $\mathrm{r}=0.004, \mathrm{r}=0.023, \mathrm{p}<0.05)$ and CRP $(\mathrm{r}=0.026, \mathrm{r}=0.041, \mathrm{r}=0.035, \mathrm{p}<0.05)$ were strongly associated with all the oxidative stress markers (MDA, NO, DNA damage respectively) (Table 6).

\section{Discussion}

Type 2 diabetic nephropathy is a multifactorial and most prevalent complication of diabetes mellitus worldwide accounting for nearly 44 percent of new cases [14]. Type 2 DM gradually affects the kidneys and kidney failure is the final stage of type $2 \mathrm{DN}$. The diabetic prevalence has extended epidemic magnitudes worldwide and is expected to rise to 350 million people by the year 2035 [15]. The risk factors for type 2 DN progression include genetic, environmental and metabolic factors like blood pressure, blood lipids, glycemic control, duration of diabetes, smoking, glomerular hypertension, inflammation, and oxidative stress worsen albuminuria.

Long-standing hyperglycemia may directly increase the mesangial cell glucose concentration and results in mesangial expansion and injury. Initially, the glomerular mesangium expands by cell proliferation and then by cell hypertrophy, this expansion is stimulated by an increase in mesangial stretch and pressure, as can high glucose levels. Hyperglycemia aggravates glomerular lesions and metabolic effects of long standing hyperglycemia causes AGE production that binds to collagen and causes renal complications. AGE containing protein increases PKC and TGF $\beta$ which plays an important role in cell proliferation, differentiation and mesangial cell apoptosis. Recent studies by researchers showed the increase of FBS and PLBS levels in type 2 DN patients [16-19]. In our study, we observed that patients in stage 5 with type 2 diabetes with more aged had significantly higher blood glucose levels compared to patients in stage 1,2, 3 and 4 .

In the blood and kidneys circulation glucose combines with proteins and forms advanced glycosylation end products (AGEs), such as glycosylated proteins of the basement membrane of the renal glomerulus contributing to increased diabetic complications [20]. Higher levels of HbAlc were associated with increased risk for development of type $2 \mathrm{DN}$. Our study was consistent with the reports by Timothy and Peter [21] where variations in HbAlc levels were strongly associated with $\mathrm{DN}$ in patients with type 2 diabetes. The mean HbAlc levels of patients with different stages of type $2 \mathrm{DN}$ patients as depicted in Table 1, show increased levels of HbAlc from stage 1 to stage 5 indicating the severity of the disease and the results are consistent with the study observed by Chen et al., [22]. Previous studies have shown that patients with $\mathrm{HbAlc}>8 \%$ are at higher risk for renal diseases [23]. Studies by Williams \& Garg [24] have revealed a significant association of $\mathrm{HbAlc}$ with clinical stages of diabetic 
Citation: Gantala SR, Kummari R, Tupurani MA, Galimudi RK, Gundapaneni KK, et al. (2018) Evaluation of Glycemic, Lipid, ImmuneInflammatory and Oxidative Stress Markers in Various Clinical Stages of Type 2 Diabetic Nephropathy. J Metabolic Synd 7: 237. doi: $10.4172 / 2167-0943.1000237$

Page 5 of 7

nephropathy, where higher HbAlc levels were associated with stage 3 and stage 4 and increased risk of mortality in diabetic nephropathy patients.

Previous studies by Daiji Kawanami et al., [25] and Chehade et al., [26] have shown that dyslipidemia facilitates glomerulosclerosis under diabetic conditions. Dyslipidemia complicated with diabetes has been shown to be involved in the development of type 2 DN. Dyslipidemia in type 2 diabetes is characterized by an increase in VLDL, LDL and TG and a decrease in HDL $[27,28]$. In the present study, we have observed high levels of triglycerides, VLDL, LDL and low levels of HDL in type $2 \mathrm{DN}$ compared to controls. These findings agreed with Jyothi Dwivedi and Sarkar [29] reports where the levels of each of T-C, TAG and LDL in type $2 \mathrm{DN}$ progression was significantly increased. However, in stage wise comparison there was no significant difference observed except for LDL which showed significant at $\mathrm{p}<0.05$.

Hyperglycemia is also associated with increased levels of ADA and CRP, playing an important role in modulation of insulin action on glucose and lipid [30,31] ADA may serve as an immune-enzyme marker in the etiopathology of type 2 DN. In a study, Prakash et al., [32] reported elevated serum ADA activity in patients with type 2 diabetes mellitus. It has been observed, with higher ADA activity in insulin-sensitive tissues, glucose uptake into cells is reduced; thus, if ADA activity is suppressed, insulin sensitivity may be improved. The high plasma ADA activity might be due to abnormal T-lymphocyte responses or proliferation. In the present study, significantly higher ADA levels were found in cases compared to controls suggesting that ADA plays a key role in the pathophysiology of type $2 \mathrm{DN}$ due to altered insulin related T-lymphocyte function [33] similar association was reported in our earlier studies on Rheumatoid Arthritis patients and Unstable Angina [34].

Hyperglycemia, insulin resistance, oxidative stress and innate immune system activation results in chronic inflammation playing a crucial role in perpetuating renal damage and progression of type 2 DN [35-37]. Dalla Vestra et al., [38] reported that patients with type 2 diabetes and overt nephropathy exhibit the highest levels of acute phase markers of inflammation, including C-reactive protein (CRP). In our study, CRP levels were found to be higher in type $2 \mathrm{DN}$ subjects compared to controls. Our results also showed a significant association of high CRP levels with low GFR values in the advanced stage of type 2 $\mathrm{DN}$. The CRP levels found is more in stage 4 and 5 compared to stage 1,2 and 3 indicating the highly active inflammatory response during the late stages of type $2 \mathrm{DN}$ (Table 5).

\begin{tabular}{|c|c|c|c|c|c|c|c|}
\hline Parameter & Biochemical variables & $\begin{array}{l}\text { Stage- } 1 \quad(n= \\
33)\end{array}$ & $\begin{array}{l}\text { Stage- } 2 \quad(n= \\
49)\end{array}$ & $\begin{array}{l}\text { Stage- } 3 \quad(n= \\
112)\end{array}$ & $\begin{array}{l}\text { Stage- } 4 \quad(n= \\
78)\end{array}$ & $\begin{array}{l}\text { Stage- } 5 \quad(n= \\
38)\end{array}$ & p-value \\
\hline \multirow{2}{*}{$\begin{array}{l}\text { Immune-inflammatory } \\
\text { markers }\end{array}$} & $\mathrm{CRP}(\mathrm{mg} / \mathrm{dL})$ & $44.16 \pm 12.22$ & $44.78 \pm 12.26$ & $46.37 \pm 13.62$ & $49.59 \pm 16.07$ & $53.06 \pm 17.88$ & $0.01 \dagger$ \\
\hline & ADA ( $\mathrm{n}$ moles $/ \mathrm{mL}$ ) & $32.68 \pm 9.93$ & $35.77 \pm 10.33$ & $35.29 \pm 11.64$ & $37.14 \pm 11.21$ & $39.09 \pm 11.24$ & 0.78 \\
\hline \multirow[b]{3}{*}{ Oxidative stress markers } & $\mathrm{NO}(\mu \mathrm{moles} / \mathrm{mL})$ & $3.22 \pm 1.24$ & $3.50 \pm 1.21$ & $3.51 \pm 1.48$ & $3.59 \pm 1.41$ & $3.89 \pm 1.81$ & $0.01 \dagger$ \\
\hline & MDA ( $\mathrm{n}$ moles $/ \mathrm{mL}$ ) & $7.59 \pm 2.47$ & $7.71 \pm 2.26$ & $7.78 \pm 3.03$ & $8.05 \pm 2.79$ & $8.17 \pm 2.15$ & $0.01 \dagger$ \\
\hline & Comet tail length $(\mu \mathrm{m})$ & $19.36 \pm 4.5$ & $22.10 \pm 5.53$ & $22.30 \pm 5.19$ & $26.28 \pm 7.13$ & $26.58 \pm 7.07$ & $0.01 \dagger$ \\
\hline \multicolumn{8}{|l|}{$†$ Significant at $p<0.01$} \\
\hline
\end{tabular}

Table 5: Immune-inflammatory \& oxidative stress markers in different stages of type $2 \mathrm{DN}$ patients.

In type $2 \mathrm{DN}$ a significant increase of these oxidative stress markers with hyperglycemia was also observed. The role of chronic hyperglycemia in type $2 \mathrm{DN}$ is thought to alter metabolism which creates oxidative stress and induces apoptotic glucose responsive cells.

Hyperglycemia represents the main cause of complication of DM, growing evidence shows that AGEs and their signal-transducing receptor interaction increases oxidative stress and subsequently elicits vascular inflammation and thrombosis resulting from the increased generation of ROS, playing a major role in the development of type 2 DN [39]. The generation of ROS has long been recognized as a typical consequence of both chronic inflammatory state and immune cell stimulation $[5,36,40]$. In type $2 \mathrm{DN}$ a significant increase of the oxidative stress markers MDA, NO, DNA damage with hyperglycemia was seen and our results were consistent with reports by KedzioraKornatowska et al., [41], where increased lipid peroxidation in erythrocytes of patients with type 2 DN was observed. Ha et al., (2001) [42] also observed increased lipid peroxidation product (MDA) in proximal tubular epithelial cells. The results of the present study also revealed that the mean values of MDA in type $2 \mathrm{DN}$ patients were significantly higher than that of the controls as observed by earlier studies and further we also found a significant difference between the patients with different stages of type $2 \mathrm{DN}$.

Over the last decade, a remarkable burst of evidence has accumulated, offering the new perspective that nitric oxide (NO) plays a pivotal role in $\mathrm{DN}$. ROS and $\mathrm{NO}$ react in pathophysiological conditions, to generate dinitrogen trioxide and peroxynitrite the two toxic reactive nitrogen species that cause significant damage to cellular components (nucleic acid, proteins, membranes) leading to chromosomal alterations, subsequent cellular dysfunction, and cellular death [43]. Excess ROS modulate protein kinase C activation, mitogenactivated protein kinases, and various cytokines and transcription factors that increase the expression of ECM genes towards progression to ESRD. ROS induces the activation of renin-angiotensin system (RAS), further worsens the renal injury in diabetic nephropathy.

Renal disease in diabetes is found to be associated with abnormalities of vasodilatation and generates ROS mediated by endothelial derived NO, suggesting linkage between vascular and metabolic abnormalities. Sharma et al., [44] observed a positive correlation between serum NO levels, GFR, and albuminuria, suggesting a link between NO, glomerular hyperfiltration and 
Citation: Gantala SR, Kummari R, Tupurani MA, Galimudi RK, Gundapaneni KK, et al. (2018) Evaluation of Glycemic, Lipid, ImmuneInflammatory and Oxidative Stress Markers in Various Clinical Stages of Type 2 Diabetic Nephropathy. J Metabolic Synd 7: 237. doi: 10.4172/2167-0943.1000237

Page 6 of 7

microalbuminuria. Similarly, we have also observed high levels of nitrite/nitrate in type $2 \mathrm{DN}$ patients compared to healthy controls which are in accordance with earlier report, but no significant difference was observed among patients with different stages of type 2 DN (Table 5).

High glucose increases ROS production in vascular cells and in renal cells including mesangial cells and tubular epithelial cells [45]. Increased ROS formation contributes to endothelial dysfunction, vessel wall thickening and lesion formation thereby playing a crucial role in the progressive deterioration of vascular structure and function [46].

ROS and their byproducts can cause oxidative damage which may be cytotoxic and may have some deleterious effects on DNA causing oxidative DNA damage resulting in cell death, loss of heterozygosity, translocations, and chromosome loss [47]. AGE-induced TGF $\beta$ expression causes glomerular basement membrane thickening, obstruction of arteries, mesangial apoptosis and dysfunction may contribute in part to glomerular hyperfiltration. Simone et al., [48] reported the presence of leukocyte DNA damage by high performance liquid chromatography in type $2 \mathrm{DN}$ patients. In the present study, we have assessed the DNA damage (Comet tail length) using the comet assay and found that there is a significant increase in DNA damage in type $2 \mathrm{DN}$ patients compared to controls.

Our study reports that patients with type $2 \mathrm{DN}$ had increased levels of oxidative stress markers (MDA, Nitric oxide and DNA damage). Therefore, it might be suggested that hyperglycemia increases the oxidative stress and causes more DNA damage as observed in the late stages of type 2 DN stage- 4, 5 compared to stage-1, 2 and 3 (Table 5).

Further blood glucose, lipid profile and inflammatory markers were correlated with oxidative stress markers and our results have shown that PLBS, LDL-C and CRP were strongly associated with all the oxidative stress markers (MDA, NO, DNA damages respectively) under study $(\mathrm{p}<0.05)$ (Table 6).

\begin{tabular}{|c|c|c|c|c|}
\hline \multicolumn{5}{|c|}{ Oxidative stress markers } \\
\hline & & MDA & NO & Comet tail length $(r)$ \\
\hline \multirow[b]{3}{*}{ Glucose profile } & FBS & $0.004 \dagger$ & $0.023^{*}$ & 0.076 \\
\hline & PLBS & $0.052^{*}$ & $0.046^{*}$ & $0.016^{*}$ \\
\hline & $\mathrm{HbA1c}$ & $0.035^{*}$ & 0.112 & $0.037^{\star}$ \\
\hline \multirow[b]{4}{*}{ Lipid profile } & TC & $0.009+$ & 0.095 & $0.042^{*}$ \\
\hline & TG & 0.113 & 0.12 & $0.035^{*}$ \\
\hline & LDL-C & $0.014^{*}$ & $0.004 \dagger$ & $0.023^{*}$ \\
\hline & HDL-C & $-0.027^{\star}$ & 0.36 & 0.065 \\
\hline $\begin{array}{l}\text { Immune- } \\
\text { inflammatory }\end{array}$ & ADA & 0.085 & 0.144 & 0.106 \\
\hline Markers & CRP & $0.026^{*}$ & $0.041^{*}$ & $0.035^{*}$ \\
\hline \multicolumn{5}{|c|}{${ }^{*}$ Correlation is significant at the level 0.05 level (2-tailed) } \\
\hline \multicolumn{5}{|c|}{ †Correlation is significant at the level 0.01 level $(2$-tailed) $(p<0.01)$} \\
\hline
\end{tabular}

Table 6: Pearson's correlation between blood glucose markers, lipid profile markers and Immune-inflammatory markers with oxidative stress markers (MDA, NO, DNA damage (Comet tail length)) in type 2 DN patients.

\section{Conclusion}

Type 2 end-stage renal disease is a devastating condition, blood glucose control is critical in preventing or slowing the progression of renal damage. Thus, from the above study, we conclude that hyperglycemia mediated regulation of immune-inflammation and oxidative stress have a significant role on development and progression of type $2 \mathrm{DN}$. Understanding the development of diabetic nephropathy and its progression into ESRD is important for the interpretation of clinical studies which helps in early diagnosis, prognosis and therapeutics.

\section{Acknowledgements}

This study was supported by contingency grant from the UGC-BSRRFSMS and UGC-MJRP for providing consumables. The sponsors of the study had no role in study design, data collection and analysis or writing of the manuscript. The authors thank all the participants in this research and special thanks are extended to medical staff of the Nizams Institute of Medical Sciences (NIMS), for their assistance.

\section{References}

1. Chan JC, Malik V, Jia W, Kadowaki T, Yajnik CS, et al. (2009) Diabetes in Asia: epidemiology, risk factors, and pathophysiology. Jama 301: 2129-2140.

2. Vos FE, Schollum JB, Coulter CV, Manning PJ, Duffull SB, et al. (2012) Assessment of markers of glycaemic control in diabetic patients with chronic kidney disease using continuous glucose monitoring. Nephrology 17: 182-188.

3. Andy $\mathrm{KH}$, Lim (2014) Diabetic nephropathy complications and treatment. Int J Nephrol Renovasc Dis 7: 361-381.

4. Cheng W, Hua S, Chun Z (2016) Role of NADPH Oxidase in Metabolic Disease-Related Renal Injury: An Update. Oxid Med Cell Longev Article ID 7813072: 8 .

5. Hojs R, Ekart R, Bevc S, Hojs N (2016) Markers of Inflammation and Oxidative Stress in the Development and Progression of Renal Disease in Diabetic Patients. Nephron 133: 159-162.

6. Asgary S, Naderi GH, Sarrafzadegan N, Ghassemi N, Boshtam M, (1999) Anti-oxidant effect of flavonoids on hemoglobin glycosylation. Pharmaceutica Acta Helvetiae 73: 223-226.

7. Friedewald WT, Levy RI, Fredrickson DS (1972) Estimation of the concentration of low-density lipoprotein cholesterol in plasma, without use of the preparative ultracentrifuge. Clin Chem 18: 499-502.

8. Giusti G, Galanti B, Gaeta GB, Piccinino F, Ruggiero G (1981) HBsAg carriers among blood donors in Italy- a retrospective survey of data from 189 blood banks. Hepato-gastroenterology 28: 96-98.

9. Meloni T, Forteleoni G, Meloni GF (1992) Marked decline of favism after neonatal glucose-6-phosphate dehydrogenase screening and health education: the northern Sardinian experience. Acta haematological 87: 29-31.

10. Lepoivre M, Chenais B, Yapo A, Lemaire G, Thelander L, et al. (1990) Alterations of ribonucleotide reductase activity following induction of the nitrite-generating pathway in adenocarcinoma cells. Journal of Biological Chemistry 265: 14143-14149.

11. Singh J, Comfort SD, Shea PJ (1998) Remediating RDX-contaminated water and soil using zero-valent iron. Journal of environmental quality 27 : 1240-1245.

12. Ahuja YR, Vijayashree B, Saran R, Jayashri EL, Manoranjani JK, et al. (1999) In vitro effects of low-level, low-frequency electromagnetic fields on DNA damage in human leucocytes by comet assay 36: 318-322.

13. Euan AS, Neeraj D, James W, David JW (2013) Measurement of renal function in patients with chronic kidney disease. Br J Clin Pharmacol 76: 504-515. 
Citation: Gantala SR, Kummari R, Tupurani MA, Galimudi RK, Gundapaneni KK, et al. (2018) Evaluation of Glycemic, Lipid, ImmuneInflammatory and Oxidative Stress Markers in Various Clinical Stages of Type 2 Diabetic Nephropathy. J Metabolic Synd 7: 237. doi: 10.4172/2167-0943.1000237

Page 7 of 7

14. Martinez-Castelao A, Navarro-Gonzalez JF, Gorriz JL, Alvaro F (2015) The concept and the epidemiology of diabetic nephropathy have changed in recent years. Journal of clinical medicine 4: 1207-1216.

15. Gheith O, Farouk N, Nampoory N, Halim MA, Al-Otaibi T (2016) Diabetic kidney disease: worldwide difference of prevalence and risk factors. Journal of Nephropharmacology 5: 49.

16. Lipska KJ, Krumholz H, Soones T, Lee SJ (2016) Polypharmacy in the aging patient: a review of glycemic control in older adults with type 2 diabetes. Jama 315: 1034-1045.

17. Schwartz AV, Vittinghoff E, Sellmeyer DE, Feingold KR, De Rekeneire N, et al. (2008) Diabetes-related complications, glycemic control, and falls in older adults. Diabetes care 31: 391-396.

18. Shurraw S, Hemmelgarn B, Lin M, Majumdar SR, Klarenbach S, et al. (2011) Alberta Kidney Disease Network Association between glycemic control and adverse outcomes in people with diabetes mellitus and chronic kidney disease: a population-based cohort study. Archives of internal medicine 171: 1920-1927.

19. Ricks J, Molnar MZ, Kovesdy CP, Shah A, Nissenson AR, et al. (2012) Glycemic control and cardiovascular mortality in hemodialysis patients with diabetes. Diabetes 61: 708-715.

20. Helen V (1996) Protein glycation in the kidney: Role in diabetes and aging. Kidney International 49: 1795-1804.

21. Timothy CE, Peter C (2000) Diabetic Nephropathy. Clinical Diabetes 18: 1.

22. Chen HS, Wu TE, Lin HD (2010) Hemoglobin A(1c) and fructosamine for assessing glycemic control in diabetic patients with CKD stages 3 and 4. Am J Kidney Dis 55: 867-874.

23. Jawa A, Kcomt J, Fonseca VA (2004) Diabetic nephropathy and retinopathy. Medical Clinics 88: 1001-1036.

24. Williams ME, Garg R (2014) Glycemic management in ESRD and earlier stages of CKD. American journal of kidney diseases 63: S22-S38.

25. Kawanami D, Matoba K, Utsunomiya K (2016) Dyslipidemia in diabetic nephropathy. Renal Replacement Therapy 2: 16.

26. Chehade JM, Gladysz M, Mooradian AD (2013) Dyslipidemia in type 2 diabetes: prevalence, pathophysiology, and management. Drugs 73: 327-339.

27. Mooradian AD (2009) Dyslipidemia in type 2 diabetes mellitus. Nature Reviews Endocrinology 5: 150.

28. Parveen K, Siddiqui WA, Kausara MA, Kuddusa M, Syed Monowar AS (2016) Diabetic Nephropathy - A Major Macrovascular Complication. International Journal of Pharmaceutical Research \& Allied Sciences 5: 132-158.

29. Dwivedi J, Sarkar PD (2017) The study of lipid profile, LP (a) and electrolytes with oxidative stress, total protein and albumin in nephrotic syndrome. J Res Med Sci Title 2: 62-66.

30. Gohe MG, Sirajwala HB, Kalaria TR, Kamariya CP (2013) A study of serum adenosine deaminase level in patients with type 2 diabetes mellitus and its correlation with glycemic control. Int J Res Med Appl Sci 2: 259-267.

31. Ramu A, Susheel Kumar N, Pankaj KB, Ayan KB, Saidulu M, et al. (2015) Hyperglycaemia Enhances Nitric Oxide Production in Diabetes: A Study from South Indian Patients. PLoS One 10: e0125270.

32. Shiva Prakash M, Chennaiah S, Murthy YSR, Anjaiah E, Ananda Rao S, et al. (2006) Altered Adenosine Deaminase Activity in Type 2 Diabetes Mellitus. JIACM 7: 114-117.
33. Mon Mohan B, Deepika L, Barnali BT (2015) A study of serum adenosine deaminase activity in type 2 diabetes mellitus with and without complications and its co-relation with serum uric acid level in glycemic control. Int J App Basic Med Res 5: 619-633.

34. Surekha Rani H, Madhavi G, Srikanth BMV, Jharna P, Rao URK, et al. (2006) Serum ADA and C - reactive protein in Rheumatoid Arthritis. Int J Hum Genet 6: 195-198.

35. Pickup JC (2004) Inflammation and activated innate immunity in the pathogenesis of type 2 diabetes. Diabetes care 27: 813-823.

36. Mima A (2013) Inflammation and oxidative stress in diabetic nephropathy: new insights on its inhibition as new therapeutic targets. J Diabetes Res 2013: 1-8.

37. Vozarova B, Weyer C, Hanson K, Tataranni PA, Bogardus C, et al. (2001) Circulating interleukin-6 in relation to adiposity, insulin action, and insulin secretion. Obesity 9: 414-417.

38. Dalla Vestra M, Mussap M, Gallina P, Bruseghin M, Cernigoi AM, et al. (2005) Acute-phase markers of inflammation and glomerular structure in patients with type 2 diabetes. Clin J Am Soc Nephrol 16: S78-S82.

39. Dwivedi J, Sarkar PD (2010) Oxidative stress with homocysteine, lipoprotein (A) and lipid profile in diabetic nephropathy 1: 340-350.

40. Muriach M, Flores-Bellver M, Romero FJ, Barcia JM (2014) Diabetes and the brain: oxidative stress, inflammation, and autophagy. Oxid Med Cell Longev 2014: 1-9.

41. Kedziora-Kornatowska KZ, Luciak M, Blaszczyk J, Pawlak W (1998) Lipid peroxidation and activities of antioxidant enzymes in erythrocytes of patients with non-insulin dependent diabetes with or without diabetic nephropathy. Nephrology, dialysis, transplantation: official publication of the European Dialysis and Transplant. Nephrol Dial Transplant 13: 2829-2832.

42. Ha H, Lee HB (2001) Oxidative stress in diabetic nephropathy: basic and clinical information. Curr Diab Rep 1: 282-287.

43. Routledge MN, Wink DA, Keefer LK, Dipple A (1994) DNA sequence changes induced by two nitric oxide donor drugs in the supF assay. Chem Res Toxicol 7: 628-632.

44. Sharma K, Danoff TM, DePiero A, Ziyadeh FN (1995) Enhanced expression of inducible nitric oxide synthase in murine macrophages and glomerular mesangial cells by elevated glucose levels: possible mediation via protein kinase C. Biochem Biophys Res Commun 207: 80-88.

45. Ha H, Lee HB (2000) Reactive oxygen species as glucose signaling molecules in mesangial cells cultured under high glucose. Kidney Int 58: S19-S25.

46. Cervelli T, Borghini A, Galli A, Andreassi MG (2012) DNA damage and repair in atherosclerosis: current insights and future perspectives. International journal of molecular sciences 13: 16929-16944.

47. Shrivastav M, De Haro LP, Nickoloff JA (2008) Regulation of DNA double-strand break repair pathway choice. Cell research 18: 134.

48. Simone S, Gorin Y, Velagapudi C, Abboud HE, Habib SL (2008) Mechanism of oxidative DNA damage in diabetes. Diabetes 57: 2626-2636. 